\title{
HUBUNGAN SUPERVISI KEPALA RUANGAN DENGAN KEPUASAN PERAWAT PELAKSANA DI RSUD LIUNKENDAGE TAHUNA
}

\author{
${ }^{1}$ Ram Marnex Tampilang \\ 2 J.S.B.Tuda \\ ${ }^{3}$ Herman Warouw
}

\author{
${ }^{1}$ Kandidat Skripsi Program Studi Keperawatan Fakultas Kedokteran \\ Universitas Sam Ratulangi Manado \\ ${ }^{2}$ Bagian Parasitologi Fakultas Kedokteran \\ Universitas Sam Ratulangi Manado \\ ${ }^{3}$ Program Studi Keperawatan Fakultas Kedokteran \\ Universitas Sam Ratulangi Manado \\ Email: ramtampilang@Gmail.com
}

\begin{abstract}
Supervision is an act of direct observations and periodically by the supervisor of the work performed by subordinates and then if there are any problems, immediately given guidance or assistance that is directly in order to cope. Satisfaction is a person's emotional response to the work he does. Job satisfaction is also inseparable from the role of the various parties, and one of them is the role of supervision. Aim for the head room supervision relationship is known to nurse satisfaction in hospitals implementing Liunkendage Tahuna. The study design is observational analytic cross-sectional approach. The population of the entire nurse practitioner working in eight wards in hospitals Liunkendage Tahuna. Sampling using purposive sampling. Data processed through the analysis of univariate and bivariate Chi Square. The results obtained by the analysis of the probability $(\mathrm{p})=0.001<\alpha(0.05)$. Conclusion, the relationship supervision chief nurse executive room with satisfaction. Advice, For the hospital in order to make improvements to the quality of head room to be included in the training and special education for the head of the room.
\end{abstract}

Keywords: supervision, head room, nurse satisfaction.

\begin{abstract}
Abstrak: Supervisi merupakan tindakan pengamatan secara langsung dan berkala oleh atasan terhadap pekerjaan yang dilaksanakan oleh bawahan untuk kemudian apabila ditemukan masalah, segera diberikan petunjuk atau bantuan yang bersifat langsung guna mengatasinya. Kepuasan merupakan suatu respons emosional seseorang terhadap pekerjaan yang dilakukannya. Kepuasan kerja ini juga tidak terlepas dari peranan berbagai pihak, dan salah satunya merupakan peran dari supervisi. Tujuan untuk diketahui hubungan supervisi kepala ruangan dengan kepuasan perawat pelaksana di RSUD Liunkendage Tahuna. Desain penelitian observasional analitik dengan pendekatan cross sectional. Populasi yaitu seluruh perawat pelaksana yang bekerja di delapan ruang rawat inap di RSUD Liunkendage Tahuna. Pengambilan sampel dengan menggunakan purposive sampling. Data diolah secara univariat dan bivariat melalui analisis Chi Square. Hasil analisis diperoleh probabilitas $(p)=0.001<\alpha$ $(0,05)$. Kesimpulan, adanya hubungan supervisi kepala ruangan dengan kepuasan perawat pelaksana. Saran, Bagi pihak rumah sakit agar dapat melakukan peningkatan mutu kepala ruangan dengan diikut sertakan pada pelatihan dan pendidikan khusus bagi kepala ruangan.
\end{abstract}

Kata kunci: supervisi, kepala ruangan, kepuasan perawat. 
Supervisi berasal dari kata uper (latin= diatas) serta videre (latin=melihat), maka supervisi berarti melakukan pengamatan secara langsung dan berkala oleh atasan terhadap pekerjaan yang dilaksanakan oleh bawahan untuk kemudian apabila ditemukan masalah, segera diberikan petunjuk atau bantuan yang bersifat langsung guna mengatasinya. ${ }^{1}$

Supervisi mencakup semua aktivitas yang diyakini manajemen akan membantu mencapai tujuan administrasi. Kegiatankegiatan yang merupakan bagian integral dari supervisi dalam keperawatan mencakup pelaporan, pembagian tugas, pemberian arahan, pengamatan, penilaian, pembimbingan, dan pendidikan pekerja. Supervisi keperawatan meyakinkan bahwa semua pasien menerima asuhan seperti yang seharusnya. Hal ini dimulai dengan memberikan laporan tentang setiap pasien kepada para staf perawat. ${ }^{2}$

Perawat dalam melaksanakan tugas sebagai penyelenggara layanan keperawatan, bukanlah sebagai pelaksana pasif, melainkan sebagai partner kerja yang memiliki ide-ide, pendapat dan pengalaman yang perlu didengar, dihargai, dan diikutsertakan dalam usaha-usaha perbaikan proses keperawatan, dengan arti bahwa supervisi itu merupakan suatu aktifitas pembinaan yang direncanakan untuk membantu para tenaga keperawatan dan staf lainnya dalam melakukan pekerjaan mereka secara aktif untuk menciptakan suatu pelayanan yang bermutu. Azwar, ${ }^{1}$ menyatakan bahwa pelayanan kesehatan yang bermutu adalah pelayanan kesehatan yang dapat memuaskan setiap pemakai jasa pelayanan kesehatan sesuai dengan tingkat kepuasan rata-rata penduduk, serta penyelenggaraannya sesuai dengan standar dan kode etik yang sudah ditetapkan. $^{3}$

Kepuasan yang ditujukkan bagi penerima layanan sangatlah penting, tetapi suatu kepuasan dari penyelenggara layanan keperawatan (perawat pelaksana) juga harus perlu diperhatikan, karena dengan adanya perhatian untuk memberikan kepuasan bagi perawat pelaksana, maka akan memberi pengaruh pada peningkatan mutu pela- yanan sebagai seorang pemberi pelayanan baik di puskesmas, rumah sakit, dan tempat pelayanan kesehatan lainnya.

RSUD Liunkendage Tahuna sebagai salah satu tempat pelayanan kesehatan, merupakan satu-satunya rumah sakit di kabupaten Sangihe, dan memiliki khusus tenaga keperawatan 216 orang dengan latar belakang pendidikan SPK 35 (sementara mengikuti pendidikan lanjutan), diploma III 165, diploma IV 5, sarjana keperawatan 2, sarjana keperawatan Ns 9. Perawat yang bekerja khusus pada delapan ruang rawat inap yang ada berjumlah 114 orang perawat (59,24\%), dan dikepalai oleh seorang penanggung jawab baik latar pendidikan diploma III keperawatan, diploma IV, maupun sarjana keperawatan Ns, yang bertanggungjawab dan berwewenang dalam mengelola kegiatan pelayanan keperawatan, termasuk didalamnya kegiatan supervisi.

Penelitian sebelumnya oleh Zachliherni Z; Universitas Muhamadiyah Semarang di RSUP Dr Kariadi Semarang, didapat suatu kesimpulan hasil bahwa terdapatnya hubungan yang signifikan antara ketrampilan, kompentensi supervisor dengan kepuasan kerja perawat pelaksana. ${ }^{4}$

Berdasarkan hal tersebut di atas maka penulis tertarik sekaligus mencoba untuk meneliti apakah ada hubungan supervisi kepala ruangan dengan kepuasan perawat pelaksana di RSUD Liunkendage Tahuna.

\section{METODE}

Jenis Penelitian yang digunakan adalah observasional analitik dengan cross sectional. Penelitian dilaksanakan pada delapan ruang rawat inap di RSUD Liunkendage Tahuna kabupaten Sangihe dengan Waktu Penelitian dilaksanakan pada bulan Januari 2013.

Populasi pada penelitian ini adalah keseluruhan dari perawat yang bertugas di ruang rawat inap RSUD Liunkendage Tahuna berjumlah 114 orang. Sampel Pada penelitian ini dilakukan dengan metode non probability sampling (purposive sampling) dengan jumlah sampel 69 orang perawat.

Kriteria inklusi yaitu perawat pelak- 
sana yang sedang melakukan tugas jaga di ruang perawatan, telah bekerja minimal satu tahun, dan bersedia diteliti. Kriteria Eklusi yaitu perawat yang sedang cuti dan sakit saat penelitian, perawat yang bertugas sebagai kepala ruangan/penangungjawab ruangan.

Instrumen Pengumpulan Data terdiri dari kareakteristik responden dengan menggunakan dua kuesioner yaitu: kuesioner tentang supervisi yang terdiri dari sepuluh pertanyaan dengan jawaban Ya atau Tidak, dengan skor dua untuk jawaban Ya dan skor satu untuk jawaban Tidak, dengan hasil dikatakan supervisi baik jika lebih dari mean, dan akan dikatakan supervisi tidak baik jika hasil supervisi kurang atau sama dengan mean, dan kuesioner tentang kepuasan yang terdiri dari sepuluh pertanyaan dengan jawaban Ya atau Tidak, dengan skor dua untuk jawaban Ya dan skor satu untuk jawaban Tidak, dengan hasil dikatakan puas jika lebih dari mean, dan akan dikatakan tidak puas jika kurang atau sama dengan mean.

Pengumpulan data dilakukan sesuai jadwal yang diatur, setelah mendapat persetujuan dari pembimbing dan penguji proposal, dengan menggunakan instrumen kuesioner. Pada lokasi penelitian dilakukan pada saat setelah mendapat izin dari pimpinan unit tempat penelitian. Kuesioner diisi oleh responden yang memenuhi kriteria setelah menandatangani persetujuan.

Pengolahan data merupakan proses penataan data, karena data yang terkumpul merupakan suatu data kasar yang perlu diolah. Pengolahan data ini terdiri dari: Editing yaitu proses dilakukan setelah memperoleh data/data terkumpul, dilakukan dengan cara; memeriksa kelengkapan data, kesinambungan data, dan keseragaman data. Coding yaitu memberikan kodekode atau tanda-tanda untuk menyederhanakan hasil pengamatan sehingga mempermudah untuk pengolahan data selanjtnya. Tabulating yaitu dilakukan untuk memudahkan dalam pengolahan data kedalam suatu tabel menurut sifat-sifat yang dimiliki sesuai dengan tujuan penelitian, tabel lebih mudah untuk dianalisis. Tabel tersebut da- pat berupa tabel sederhana maupun tabel silang.

Analisa data untuk melihat hubungan supervisi kepala ruangan dengan kepuasan perawat pelaksana di RSUD Liunkendage Tahuna. Dimana data dianalisis dengan menggunakan uji chi-square $\left(x^{2}\right)$ pada kemaknaan 95\% ( $\alpha 0,05)$, dengan bantuan SPSS 20.

Etika penelitian bertujuan untuk menjaga kerahasiaan identitas responden akan kemungkinan terjadinya ancaman terhadap res-ponden. Masalah etika ini terutama ditekankan pada: Infomend Consent. Lembar persetujuan ini diserahkan kepada responden yang mengisi kuesioner yang memenuhi kriteria inklusi, dan jika subjek menolak maka peneliti akan tetap menghargai hakhak mereka. Anonimity (tanpa nama) Pada kuesioner subjek tidak perlu mencantumkan nama, tetapi dapat diberikan suatu kode atau inisial untuk menjaga kerahasiaan. Confidentialy (kerahasiaan) Kerahasiaan dari responden sangat dijamin, dimana peneliti hanya mau melaporkan data-data tertentu sebagai hasil dari penelitian.

\section{HASIL}

\section{Analisis Univariat}

Setelah melakukan penelitian selama satu minggu, maka peneliti memperoleh sampel sebanyak 69 perawat, dengan karakteristik sebagai berikut:

Tabel 1. Distribusi responden menurut ruangan.

\begin{tabular}{ccc}
\hline \multirow{2}{*}{ Ruangan } & \multicolumn{2}{c}{ Banyaknya responden } \\
\cline { 2 - 3 } & $\mathrm{n}$ & $\%$ \\
\hline $\mathrm{A}$ & 8 & 12 \\
$\mathrm{~B}$ & 12 & 17 \\
$\mathrm{C}$ & 8 & 12 \\
$\mathrm{D}$ & 7 & 10 \\
$\mathrm{E}$ & 10 & 14 \\
$\mathrm{~F}$ & 9 & 13 \\
Neonati & 8 & 12 \\
ICU & 7 & 10 \\
\hline total & 69 & 100 \\
\hline
\end{tabular}


Tabel 2. Distribusi menurut pendidikan.

\begin{tabular}{ccc}
\hline \multirow{2}{*}{ pendidikan } & \multicolumn{2}{c}{ Banyaknya responden } \\
\cline { 2 - 3 } & $\mathrm{n}$ & $\%$ \\
\hline SPK & 6 & 9 \\
D3 & 62 & 90 \\
S1 & 1 & 1 \\
\hline total & 69 & 100 \\
\hline
\end{tabular}

Tabel 3. Distribusi menurut masa kerja.

\begin{tabular}{ccc}
\hline \multirow{2}{*}{ Masa kerja } & \multicolumn{2}{c}{ Banyaknya responden } \\
\cline { 2 - 3 } & $\mathrm{n}$ & $\%$ \\
\hline$<10$ thn & 60 & 87 \\
$10-20$ thn & 9 & 13 \\
$>20$ thn & 0 & 0 \\
\hline total & 69 & 100 \\
\hline
\end{tabular}

Tabel 4. Distribusi Responden Menurut Supervisi Kepala Ruangan.

\begin{tabular}{ccc}
\hline Supervisi kepala & \multicolumn{2}{c}{ Banyaknya responden } \\
\cline { 2 - 3 } ruangan & $\mathrm{n}$ & $\%$ \\
\hline Tidak baik & 19 & 28 \\
baik & 50 & 72 \\
\hline total & 69 & 100 \\
\hline
\end{tabular}

Tabel 5. Distribusi Responden Menurut Kepuasan Perawat Pelaksana.

\begin{tabular}{ccc}
\hline Kepuasan Perawat & \multicolumn{2}{c}{ Banyaknya responden } \\
\cline { 2 - 3 } Pelaksana & $\mathrm{n}$ & $\%$ \\
\hline puas & 42 & 61 \\
tidak puast & 27 & 39 \\
\hline total & 69 & 100 \\
\hline
\end{tabular}

\section{Analisis Bivariat}

Tabel 6. Distribusi Responden Menurut Hubungan Supervisi Kepala Ruangan Dengan Kepuasan Perawat Pelaksana.

\begin{tabular}{cccc}
\hline \multirow{2}{*}{$\begin{array}{c}\text { Supervisi } \\
\text { kepala }\end{array}$} & \multicolumn{2}{c}{$\begin{array}{c}\text { Kepuasan perawat } \\
\text { pelaksana }\end{array}$} & \\
\cline { 2 - 3 } ruangan & Puas & $\begin{array}{c}\text { Tidak } \\
\text { Puas }\end{array}$ & \\
\cline { 2 - 3 } & $\mathrm{n}$ & $\mathrm{n}$ & \\
\cline { 2 - 3 } & $\mathrm{n}$ & 13 & 50 \\
Baik & 37 & 14 & 19 \\
\hline Tidak Baik & 5 & &
\end{tabular}

\begin{tabular}{cccc}
\hline Total & 42 & 27 & 69 \\
\hline BAHASAN & & &
\end{tabular}

Penelitian dilakukan pada perawat yang bekerja di delapan ruangan rawat inap di RSUD Liunkendage Tahuna, peneliti memperoleh 69 responden, berdasarkan responden ini, maka dapat dinyatakan perawat yang ada di delapan ruang rawat inap RSUD Liunkendage Tahuna sebagian besar berpendidikan D3 dengan masa kerja kurang dari 10 tahun. Supervisi kepala ruangan pada keadaan supervisi yang baik, sedangkan kepuasan perawat pelaksana pada tingkat puas.

Analisis bivariat supervisi kepala ruangan dengan kepuasan perawat pelaksana di RSUD Liunkendage Tahuna dari 69 responden, menunjukkan dominan pada supervisi kepala ruangan baik kepuasan perawat pelaksana puas. Hasil uji hipotesis dengan menggunakan uji chi-square $\left(x^{2}\right)$ pada kemaknaan 95\% ( $\alpha$ 0,05) bantuan SPSS 20, diperoleh nilai $p=0,001$. Pengujian ini dapat dilihat bahwa nilai $p$ $(0,001)$ yang diperoleh, lebih kecil dari $\alpha$ $(0,05)$ ini menjelaskan bahwa terjadi penolakan terhadap Ho atau Ha di terima berarti ada hubungan antara supervisi kepala ruangan dengan kepuasan perawat pelaksana di RSUD Liunkendage Tahuna. Hasil pengujian adanya hubungan antara supervisi kepala ruangan dengan kepuasan perawat pelaksana di ruang rawat inap RSUD Liunkendage Tahuna, menunjukkan adanya kemiripan dengan penelitian yang dilakukan sebelumnya di RSUP Dr Kariadi Semarang oleh Zachliherni Z, ${ }^{4}$ Universitas Muhamadiyah, dimana didapat suatu kesimpulan terdapatnya hubungan yang signifikan antara ketrampilan, kompetensi supervisor dengan kepuasan kerja perawat pelaksana.

Kepala ruangan merupakan seorang tenaga perawat profesional yang bertanggung jawab dan berwenang dalam mengelola kegiatan pelayanan keperawatan di suatu ruangan. ${ }^{5}$ Dalam menjalankan tanggung jawabnya, kepala ruangan mengelola ruangan secara profesional dengan mengacu pada standar yang telah ditetapkan oleh 
depkes, untuk mencapai tujuan pelayanan keperawatan yang berkualitas melalui pelaksanaan fungsi perencanaan, pengorganisasian, pengaturan ketenagaan, pengarahan, evaluasi dan pengendalian mutu pelayanan keperawatan. Kepala ruangan dalam mengelola pelayanan keperawatan di Rumah Sakit adalah sebagai seorang manajer tingkat lini yang mempunyai tanggung jawab untuk meletakan konsep praktik, prinsip dan teori manajemen keperawatan serta mengelola lingkungan organisasi untuk menciptakan iklim yang seoptimal dan senyaman mungkin dan menjamin kesiapan dalam asuhan keperawatan oleh perawat klinik.

Suarli, ${ }^{2}$ menyatakan bahwa yang bertanggungjawab untuk melaksanakan supervisi adalah atasan yang memiliki kelebihan dalam organisasi. Idealnya kelebihan tersebut tidak hanya dari aspek status dan kedudukan, tetapi juga pengetahuan dan ketrampilan. Berdasarkan hal tersebut serta prinsip-prinsip pokok supervisi, untuk dapat melakukan supervisi dengan baik, ada beberapa syarat atau karakteristik yang harus dimiliki oleh pelaksana supervisi (supervisor) yaitu; atasan langsung, memiliki pengetahuan dan ketrampilan, memahami ketrampilan dan teknik supervisi, memiliki sifat edukatif dan suportif (bukan otoriter), mempunyai waktu yg cukup, sabar, serta selalu mengutamakan yang disupervisi. Seorang supervisor jika ingin menjadi pelaksana supervisi yang baik, manejer perlu mengikuti pendidikan dan pelatihan yang bersifat khusus.

Kepuasan penyelenggara layanan kesehatan (perawat pelaksana) sangatlah penting, tetapi kepuasan ini sering terabaikan atau terlupakan. Penyelenggara layanan kesehatan yang frustrasi dan kecewa atau tidak puas akan menjadi kurang produktif dan kurang efisien. Kepuasan penyelenggara dalam jangka panjang akan mempunyai dampak ekonomi. Kepuasan penyelenggara memberi arah terhadap harapan, sedang audit akan mengarah kepada petunjuk pelaksana kerja. Dengan demikian pengukuran kepuasan penyelenggara selalu harus dilihat dalam hubungannya dengan harapan-harapan. ${ }^{6}$

Tingkat kepuasan merupakan fungsi dari perbedaan antara kinerja yang dirasakan dengan harapan. Apabila kinerja dibawah harapan, maka pelanggan akan sangat kecewa, tetapi bila kinerja sesuai dengan harapan, maka pelanggan akan sangat puas. Pelanggan yang puas akan setia lebih lama, kurang sensitif terhadap harga, dan memberi komentar yang baik tentang perusahan tersebut. Kepuasan kinerja dinilai dari dimensi pekerjaan yang terdiri dari; pengawas atau pemimpin, upah, promosi, rekan kerja. $^{7}$

Supervisi kepala ruangan dan kepuasan perawat pelaksana sangat erat kaitan dan hubungannya. Hasi menunjukkan bahwa berdasarkan distribusi responden menurut supervisi kepala ruangan sebanyak 69 orang, 50 responden menyatakan bahwa supervisi kepala ruangan yang ada di RSUD Liunkendage Tahuna baik, tetapi walaupun supervisi ini dalam keadaan baik, masih ada responden yang belum puas dengan supervisi yang dilakukan oleh seorang kepala ruangan. Ini mengisyaratkan bahwa seorang kepala ruangan perlu untuk mempertahankan dan meningkatan supervisi yang telah ada, dengan mengutamakan sasaran yang disupervisi, menciptakan suasana kerja yang senyaman mungkin bagi seluruh stafnya sehingga pelayanan yang berkualitas dapat terwujud.

Berdasarkan distribusi menurut kepuasan perawat pelaksana masih terdapat responden tidak puas dengan supervisi yang dilakukan oleh kepala ruangan. Hal di atas menyatakan kepala ruangan sangat perlu mempertahankan dan lebih meningkatkan tanggungjawabnya sehingga dapat memberikan kenyamanan bagi perawat pelaksana dalam melakukan tugas.

Hubungan supervisi kepala ruangan dengan kepuasan perawat pelaksana di RSUD Liunkendage Tahuna dominan menunjukkan supervisi kepala ruangan baik kepuasan perawat pelaksana puas. Walaupun dominan seperti ini, terdapat lima responden yang menyatakan supervisi kepala ruangan tidak baik namun puas. Hal ini bisa disebabkan karena faktor masa 
kerja atau kesenioran, dimana kepala ruangan dirasakan lebih mudah dalam usia maupun masa kerjannya.

Penerapan supervisi kepala ruangan sangat perlu diperhatikan sebab jika supervisi kepala ruangan itu dalam keadaan baik maka akan memberikan kepuasan terhadap perawat pelaksana yang disupervisi, tetapi jika sebaliknya yaitu supervisi dalam keadaan tidak baik, maka akan memberikan dampak ketidak puasan bagi perawat pelaksana. Oleh sebab itu tindakan supervisi dari seorang kepala ruangan sangat perlu dilakukan sebaik mungkin dengan memperhatikan atau mengutamakan apa dan siapa yang akan disupervisi.

\section{SIMPULAN}

Penerapan tindakan supervisi kepala ruangan yang ada di ruang rawat inap RSUD Liunkendage Tahuna berdasarkan penelitian menunjukkan sebagian besar supervisi kepala ruangan yang baik. Perawat pelaksana yang ada di ruang rawat inap RSUD Liunkendage Tahuna sebagian besar puas terhadap tindakan supervisi kepala ruangan. Terdapat hubungan yang signifikan antara supervisi kepala ruangan dengan kepuasan perawat pelaksana di RSUD Liunkendage Tahuna, dimana nilai $p=0,001$.

\section{SARAN}

Bagi pihak rumah sakit yang lebih khususnya kepada kepala ruangan kiranya dapat mempertahankan dan meningkatkan tanggung jawabnya dengan sebaik-baiknya, menciptakan suasana kerja senyaman mungkin dengan tetap dapat melakukan tindakan supervisi baik yang dapat memberikan kepuasan bagi perawat pelaksana, sehingga tercapainya pelayanan rumah sakit yang berkualitas. Hasil penelitian ini diharapkan dapat menjadi sumber dasar untuk dapat dilanjutkan pada penelitian dengan skala yang lebih besar, dengan jum- lah sampel yang lebih banyak dan ditempat yang lebih luas. Bagi pihak Rumah Sakit agar dapat memperhatikan untuk melakukan peningkatan mutu kepala ruangan dengan diikutsertakan dalam pelatihan atau pendidikan khusus kepala ruangan.

\section{UCAPAN TERIMA KASIH}

1. Dr.dr. J. S. B. Tuda, M.Kes. SpPar-K, yang telah memberikan motivasi dan arahan selama penyusunan skripsi.

2. Herman Warouw, SKM, M.Kep, yang telah memberikan motivasi dengan arahan selama penyusunan skripsi.

3. Drs Julianus Ake, M.Kep, memberikan masukan dalam penulis menyelesaikan skripsi.

4. Fredna J. M. Robot, S.Kep, M.Kep, memberikan arahan serta masukan bagi penulis.

Responden yang telah memberikan data melalui pengisian kuesioner dan semua pihak yang tidak dapat disebutkan yang telah membantu dalam penulisan ini.

\section{DAFTAR PUSTAKA}

1. Azwar A. Pengantar Administrasi Kesehatans. Ciputat-Tangerang: Penerbit Binarupa Aksara, 2010.

2. Suarli S. Manajemen Keperawata dengan pendekatan praktis. Jakarta: Erlangga

3. Asmuji. Manejemen Keperawatan, Konsep dan Aplikasi. Jogjakarta: Penerbit Ar-Ruzz Media, 2012.

4. Zachliherni Z. Hubungan Supervisi Kepala Ruangan Dengan Kepuasan Kerja Perawat Pelaksana di Instalasi Rawat Inap B RSUP Dr Kariadi Semarang. Universitas Muhamadiyah Semarang [homepage on the Internet]. 2010 [cited 2013 Jan 04]. Available from: Htt:/digilib.unimus.ac.id.

5. Departemen Kesehatan RI. Pedoman Kerja Perawat Kamar Operasi. Jakarta, 2003.

6. Pohan Imbalo S. Jaminan Mutu Layanan Kesehatan. Jakarta: Penerbit EGC, 2007.

7. Kreitner R, Kinicki A. Perilaku Organisasi. Jakarta: Salemba Empat, 2005. 